\title{
The Controversy on AB2072
}

\section{Megan Malzkuhn}

\section{Description:}

Community advocate, Megan Malzkuhn, describes her experience with the State of California Assembly Bill 2072, which proposes a law for the state to distribute brochures for parents of newly identified deaf babies.

\section{Translation:}

Special interest groups with a lack of ethics are currently making their way through the Capitol in Sacramento to lobby for the bill AB 2072. On one hand, in the legal prose, AB 2072 is about parents' choice for their Deaf newborns. On the other hand, analyzing the jargon, it is about corporations' eagerness to privatize human beings.

The Deaf and bilingual community have done everything by the book to save the future of Deaf newborns. They went to Sacramento to lobby politicians to oppose AB 2072. They showed up at the hearings and floor votes. They made video testimonials. They wrote articles. They called the Assemblymen and Senators to oppose the bill. They tried to meet with Assemblyman Tony Mendoza, the author of AB 2072, several times even though Mendoza repeatedly ignored them. They exhausted their options. They are educators of the Deaf, parents of Deaf children, siblings of Deaf, mental health counselors, social workers in vocational rehabilitation field, grassroots community members, college professors, business owners, non-profit organizers, interpreters, and many more in the spectrum of the Deaf community. They knew the bill was not balanced and catered to special interest groups. The only thing they did and do not have: money.

An implanted Deaf child can produce a profit of \$60,000 and up. They undergo intensive speech and audiological training before and after they get their cochlear implant. One cochlear implant costs upwards of $\$ 40,000$. That does not include the training before and after the surgery. The audiologists who meet parents and diagnose their child's hearing loss have plenty of brochures, fliers, magazines, and even CDs and DVDs on the Audio Verbal Therapy (AVT) approach.

A private school education, concentrating on AVT can cost parents plenty of money. It will take years of continuous therapy to reach an acceptable degree of verbal communication, such as speaking on the telephone, ordering food at restaurants, and even simply saying "I love you." Private institutions and companies are purposefully vague on the statistics regarding how successful (What's success? What's considered as an acceptable measure of success?) a child is after getting a cochlear implant. 


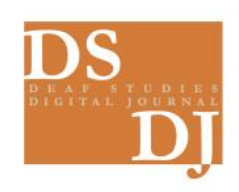

Those private institutions and associations in the field of AVT, as well as the cochlear implant industry, along with audiologists, doctors, and other specialists stand to reap millions upon millions profiting on Deaf children if all parents opt for an oral education. These combined groups listed created a special interest group under the guise of California Medical Association (CMA), California Hospital Association (CHA), California Academy of Audiology (CAA), American Federation of State, County, and Municipal Employees (AFSCME), California Speech-Language Hearing Association (CSLHA), California Coalition of six different private oral schools, and California Association of Private Special Education Schools (CAPSE, which has its own lobbying group). The California Coalition in turn is financed by giants in oral education such as Alexander Graham Bell Association for the Deaf and Hard of Hearing (AGB), Oberkotter Foundation, and Option Schools. Digging further, one can find out that the corporate founders of AGB are the only bigwigs in the cochlear industry in this country: Cochlear Americas and Advanced Bionics.

The opposition towards AB 2072 requested to investigate the accountability of the bill. Most of the people who make up the opposition are Deaf themselves, growing up in a community where they use ASL and work with Deaf children who are either fluent in ASL or might have been reared in the oral education approach. To this date, all of their amendments, suggestions, perspectives, and protestations were ignored. Assemblyman Mendoza has disregarded Deaf people, who know what it is like to be Deaf living in this state, and intends to provide the parents with all the options from everyone except for the collective signing community.

The AB 2072 bill was recognized as flawed, and catered to special interest groups. Despite the deaf community's opposition it has been passing with flying colors throughout the floors of Assembly and currently the Senate. There is only one answer to this: money.

Assemblyman Tony Mendoza, the author of the bill, was given a total of $\$ 40,800$ from three associations: CMA, CHA, and AFSCME California. There are twenty senators out of thirty-nine who have received more than $\$ 30,000$ in contributions each from these same special interest groups. In total a staggering $\$ 1,203,326$ has been donated, from the top six sponsors based on the Legislative analysis of the bill. CMA takes the lead, with $\$ 698,649$ funneled into the senators' campaign funds. The next two top players are AFSCME California with $\$ 299,900$ and CHA with $\$ 147,127$. It is no small wonder as to why the senate showed a lack of interest in listening to every side of this bill. It is not surprising how quickly the bill went through different committees and the floor of Assembly. These very same names that were mentioned above show up on AB 2072 as the bill sponsors.

Researching further on the Internet, one can find out that Tony Mendoza is widely regarded as a sleazy politician for his willingness to work with those who can fund him. He is not the only one at the Capitol in Sacramento concerning himself with special interest groups. This is a disease happening everywhere in this country. We, the opposition of AB 2072, are taking a stand against this type of one-sided information. Our side is a mere plankton facing a mammoth blue whale of corporate greed. The only thing that can set the truth free is our laws protecting freedom of speech and justice. We need to divorce from the medical experts with a multi-million interest in the direct rape of deaf babies. Now is the time to make our final stand. 


\section{Note:}

This is an edited version of "The Last Stand for the Deaf in California" which was published in The Cutting Edge News on August 23, 2010: http://www.thecuttingedgenews.com/index.php? $\underline{\text { article }=12511}$

\section{References:}

"About OPTION Schools." Auditory Oral Schools (OPTION Schools, OPTIONschools.org, Oral Deaf, Listening and Spoken Language). Web. 17 Aug. 2010. <http://

auditoryoralschools.org/aboutus.aspx>.

American Speech-Language-Hearing Association. Press Room. Cochlear Implants Quick Facts. American Speech-Language-Hearing Association. 2010. Web. 17 Aug. 2010. <http://

www.asha.org/about/news/tipsheets/cochlear_quickfacts.htm>.

California. Department of Health. Assembly Committee on Health. Official California Legislative Information. By Tony Mendoza. 19 Apr. 2010. Web. 17 Aug. 2010. <http://

www.leginfo.ca.gov/pub/09-10/bill/asm/ab_2051-2100/

ab_2072_cfa_20100419_093929_asm_comm.html>.

"California Newborn Hearing Screening Program." California Newborn Hearing Screening Program. State of California, 2007. Web. 17 Aug. 2010. <http://www.dhcs.ca.gov/

services/nhsp/Pages/default.aspx>.

"Cochlear Implants Frequently Asked Questions." U S Food and Drug Administration. U S Food and Drug Administration, 26 June 2006. Web. 17 Aug. 2010. <http://www.fda.gov/

MedicalDevices/ProductsandMedicalProcedures/ImplantsandProsthetics/

CochlearImplants/ucm062866.htm>.

"Corporate Partnership Program." Alexander Graham Bell Association for the Deaf and Hard of Hearing. 2005. Web. 17 Aug. 2010. <http://agbell.org/NetCommunity/Page.aspx?

pid $=477>$.

"Corporate Partnership Program." Alexander Graham Bell Association for the Deaf and Hard of Hearing. Ed. AGBell. 2005. Web. 17 Aug. 2010. <http://agbell.org/NetCommunity/

Page.aspx?pid=477>.

Cost and Funding - Cochlear Implants - Quick Guides. Rep. Healthy Hearing, 28 Oct. 2008. Web. 17 Aug. 2010. <http://www.healthyhearing.com/guides/guide-to-cochlearimplants/cost-funding-cochlear-implants>.

CSUS. "Eugenics in California - CSHPE - CSUS." Eugenics In California. California State University of Sacramento, 15 Nov. 2005. Web. 17 Aug. 2010. <http://www.csus.edu/ cshpe/eugenics/>.

Elias, Tom. "Corporate Money Tries to Buy California Again - Press-Telegram." Press-Telegram. Los Angeles Newspaper Group, 8 Aug. 2010. Web. 17 Aug. 2010. <http://

www.presstelegram.com/opinions/ci_15782495>. 
"Former CFO Turns In Cochlear Americas for Illegal Kickbacks." What Does Health Insurance Pay for Cochlear Implants? 10 June 2010. Web. 17 Aug. 2010. <http://

www.cochlear.org/sys-tmpl/whistleblowercomplaint/>.

Gantz, Bruce. Department of Otolaryngology - Head and Neck Surgery. Frequently Asked

Questions. University of Iowa Hospitals and Clinics, Apr. 2000. Web. 17 Aug. 2010.

$<$ http://www.uihealthcare.com/topics/medicaldepartments/otolaryngology/cochlearfaq/

index.html>.

"Guidelines for Audiologists Providing Informational and Adjustment Counseling to Families of Infants and Young Children With Hearing Loss Birth to 5 Years of Age." Untitled

Page. Web. 17 Aug. 2010. <http://www.asha.org/docs/html/

GL2008-00289.html\#sec1.4.4>.

Levin, Dan. "The Cutting Edge News." The Cutting Edge News. 21 June 2010. Web. 17 Aug.

2010. <http://www.thecuttingedgenews.com/index.php?article=12306>.

Lovley, Erika. "Obama Biggest Recipient of BP Cash." POLITICO.com. Capitol News Company

LLC, 5 May 2010. Web. 17 Aug. 2010. <http://www.politico.com/news/stories/

0510/36783.html>.

Malzkuhn, Megan. AB2072's Agenda. Rep. Stop AB2072 Now!, Apr. 2010. Web. 17 Aug. 2010.

<http://www.opposeab2072.com/?page_id=116>.

Malzkuhn, Megan. Corporate Contributions Towards AB 2072. 15 Aug. 2010. Web. 17 Aug.

2010. <https://spreadsheets.google.com/ccc?

key=0Au2gZOIJJ24rdHB4S1RLbFBiMlBEaDJLY24yaGlXQXc\&hl=en\#gid=0>.

Malzkuhn, Megan. Corporate Contributions Towards AB 2072. Digital image. Google Docs -

Online Documents, Spreadsheets, Presentations, Surveys, File Storage and More. 15

Aug. 2010. Web. 17 Aug. 2010. <https://spreadsheets.google.com/ccc?

key=0Au2gZOIJJ24rdHB4S1RLbFBiMlBEaDJLY24yaGlXQXc\&hl=en\#gid=0>.

Mason, Robert L. "Tony Mendoza, the AB 2072 Guy Is a Dirty Pol!" Web log post. RLMDEAF. 16 Aug. 2010. Web. 17 Aug. 2010. <http://robertmason.blogspot.com/2010/08/tonymendoza-ab-2072-guy-isdirty-pol.html>.

McGreevy, Patrick. "Six Lawmakers Quizzed by State Ethics Enforcer [Updated]| PolitiCal | Los Angeles Times." Los Angeles Times. Tribune, 11 May 2010. Web. 17 Aug. 2010.

<http://latimesblogs.latimes.com/california-politics/2010/05/six-lawmakers-quizzedby-state-ethicsenforcer.html>.

National Institute on Money in State Politics | Follow The Money. Web. 17 Aug. 2010. <http:// www.followthemoney.org>.

"Oral Deaf Education." Oral Deaf Education. Oberkotter Foundation, 2009. Web. 17 Aug. 2010. <http://www.oraldeafed.org/>.

Reader, Danielle and Cedric. "Interview with Hearing Parents of a Deaf Son." Interview by Tara Holcomb and Kristen Weiner. Video blog post. Stop AB2072 Now! Web. 17 Aug. 2010. 
<http://www.opposeab2072.com/?p=645>.

Search State and Federal Campaign Contribution Data - TransparencyData.com. Web. 17 Aug. 2010. <http://transparencydata.com>.

"What Does Health Insurance Pay for Cochlear Implants?" What Does Health Insurance Pay for Cochlear Implants? 10 June 2010. Web. 17 Aug. 2010. <http://www.cochlear.org/systmpl/door/>.

Woolfolk, John. "Private Interest Bills Still Win California Legislative Support - Inside Bay Area." Inside Bay Area. Bay Area News Group, 8 Aug. 2010. Web. 17 Aug. 2010.

<http://www.insidebayarea.com/ci_15696975?IADID=Searchwww.insidebayarea.com-www.insidebayarea.com>. 